\title{
Sustainability of Human Resource Management Processes through Employee Motivation and Job Satisfaction
}

\author{
Miloš Hitka ${ }^{1}$, Jarmila Schmidtová ${ }^{1}$, Silvia Lorincová ${ }^{1 *}$, Peter \\ Štarchoň² $^{2}$ Dagmar Weberová ${ }^{3}$, Rudolf Kampf ${ }^{4}$
}

${ }^{1}$ Technical University in Zvolen, Faculty of Wood Sciences and Technology, T. G. Masaryka 24, 96053 Zvolen, Slovakia, hitka@tuzvo.sk, jarmila.schmidtova@tuzvo.sk, silvia.lorincova@tuzvo.sk

${ }^{2}$ Comenius University in Bratislava, Faculty of Management, Odbojárov 10, P.O. BOX 95, 82005 Bratislava, Slovakia, peter.starchon@fm.uniba.sk

${ }^{3}$ Tomas Bata University in Zlín, Faculty of Multimedia Communications, nám. T. G. Masaryka 5555, 76001 Zlín, Czech Republic, weberova@utb.cz

${ }^{4}$ The Institute of Technology and Business in Ceske Budejovice, Faculty of Corporate Strategy, 37001 Ceske Budejovice, Czech Republic, kampf@mail.vstecb.cz

\footnotetext{
Abstract: Small and medium-sized enterprises form a significant part of the economy of each country with the greatest potential for growth and the impact on stabilizing the economy. Their success or failure depends not only on know-how, capital, or machinery, but also on human resources, one of the competitive advantages and a critical factor of success. In order to achieve success and ensure the sustainability of business processes, the focus is on employee motivation and employee satisfaction, with an emphasis on effective management as multicultural workers' groups are becoming the current trend in logistics companies. Using Tukey's HSD post-hoc test and ANOVA, differences in the perception of motivation and job satisfaction of employees are identified. As part of the post-hoc analysis, the observed dependencies of the mean values of importance and satisfaction with the effect of selected motivation factors are examined in more detail. Based on the results, the fact that employee motivation in logistics companies in Slovakia and the Czech Republic is different, can be concluded. In addition, it varies according to the size of the enterprise. These findings are important for the members of management because of the globalization of economies and multiculturalism of workers 'teams in both logistics and also other enterprises. Finding a variety of preferences for motivational needs and job satisfaction does not make it possible to develop unified motivation programs. The needs of employees regarding the size of the enterprise and also the country of origin must be taken into account by the management of an enterprise.
} 
Keywords: strategic human resource management; innovative and sustainable business practices; optimization of sustainable human resource management strategies; employee motivation; job satisfaction; employee satisfaction and productivity

\section{Introduction and Literature Background}

Small and medium-sized enterprises are considered the most flexible, efficient, most progressive and therefore the most important part of the economy in developed countries [1]. They offer a number of benefits that large businesses are not usually able to provide. Flexibility, fast response to changes in the environment, ease of decision-making, implementation of innovations, and high market focus belong to the most valuable features of small and medium-sized enterprises [2]. Many large businesses rely on small and medium-sized enterprises to provide their support services and products so that they can focus on their core business, and this is the reason that small and medium-sized businesses are highly valued for their creativity [3, 4].

Category of small and medium-sized enterprises is defined by the European Commission [5] as a set of enterprises employing less than 250 people and having either an annual turnover not exceeding EUR 50 million, or assets in an annual balance sheet not exceeding EUR 43 million. Micro-enterprises employ fewer than 10 people and their annual turnover and/or total annual balance sheet does not exceed EUR 2 million. Small businesses employ fewer than 50 people and their annual turnover and/or total annual balance sheet does not exceed EUR 10 million. Medium-sized enterprises are defined as enterprises employing fewer than 250 people and their annual turnover does not exceed EUR 50 million and/or their total annual balance sheet does not exceed EUR 43 million. Large enterprises employ more than 250 employees or their annual turnover exceeds EUR 50 million or their total annual balance sheet exceeds EUR 43 million [6].

There are more than 23 million businesses in the European Union. Total of 98.7\% of them are represented entrepreneurs and small businesses with up to 49 employees. Moreover, the smallest enterprises up to ten employees (93\%) dominate this group. Companies with 50 to 249 employees have a $1 \%$ share and, on average, only two out of a thousand companies (0.2\%) are large companies with 250 and more employees. On average, small businesses generate every second job in the EU, further $17 \%$ are medium-sized enterprises and $33 \%$ are large enterprises with 250 and more employees [7]. According to the Eurostat, European Statistical Office survey, small and medium-sized enterprises (SMEs) account for half of the volume of trade within the EU. In total, this represents 51\% of the total import volume and $45 \%$ of the volume of export within the EU. In Slovakia, small and medium-sized enterprises make up $99.9 \%$ of the total number of business entities. $96.9 \%$ of small and medium-sized enterprises are micro- 
enterprises employing fewer than 10 employees [8]. Up to $56 \%$ of employees work in micro-enterprises. Medium-sized companies in Slovakia generate 16\% of the jobs and the remaining $28 \%$ are generated by the largest enterprises [7]. In the year 2017, the share of small and medium-sized enterprises in the total number of active business entities was $99.8 \%$ in the Czech Republic. In 2017, the share of added value was $54.6 \%$. The share of small and medium-sized enterprises in the total number of employees in the business sphere was 58.0\% [9].

Enterprises make up a significant part of the economy of each country. Their success or failure does not depend only on know-how, capital, or machinery, but also on human resources, which are undoubtedly one of the competitive advantages and one of the critical factors of success of companies. Human resource management is the most important component of corporate governance in all businesses [10, 11]. It is particularly human resources that have a specific position within all strategic sources. Compared with others, they are able, based on their internal potential, to increase their level of performance, to ensure an increase in the level of other strategic resources, to adjust spontaneously their structure to changing external and internal conditions $[12,13]$.

As each company works primarily with people, their abilities and talents, the main objective of the whole human potential development system is to create the conditions to meet the enterprise business concept by maximizing the performance of each employee. The performance of employees, groups and the whole of the company as a total potential and as the overall summary of physiological and psychological abilities to deliver sustainable, desirable and appropriate performance should be cultivated and developed in a sophisticated way together with the motivation, which is the key and most dynamic attribute of each personality (individual and group). Employees and groups are supposed to be motivated systematically that can result in motivational processes leading to effective and thoughtful action $[14,15]$. With regard to the size of the business, the manager's role is to manage the employees properly $[16,17]$. The manager's capabilities, knowledge and achieved experience result in motivation of subordinates to create a sense of personal benefit in accordance with the business management intentions and, in this respect, a sense of satisfaction [18, 19]. Motivation is a dynamic process driven by personal, socio-psychological, and context factors interacting with one another [20]. It is a process responsive to individual intensity, direction, and ongoing efforts to achieve the goal. It represents a permanent process of efficiency and effectiveness asking for constant and systematic attention [21]. A competitive advantage as well as the sustainability of business processes due to higher productivity can be achieved by an enterprise through employee motivation $[22,23]$.

The application of motivation to practice is implemented through the enterprise motivation program. It is a comprehensive set of measures in the field of human resources management, which, following the other management activities of management, aims to influence actively work performance and behavior. 
Work satisfaction, as the subjective side of every person executing work in the enterprise is an inseparable part of motivation. It is a reflection of their work and its conditions in the context of individual standards, value orientation, aspirations and expectations related to the performed activities. The objective aspect of job satisfaction is expressed by such manifestations of human working behavior as performance, efficiency, quality of work results, etc., both (subjective and objective) sides are linked, but for example, the good quality of one side does not mean that the second side must also be favorable. It is not always true that a satisfied employee is automatically efficient because, for example they can be happy just because they are inefficient. Work satisfaction in the broad sense of the word is a positive or a positive emotional relationship based on performance and additionally, on the evaluation of the work. It is the attitude of a man to work. Previous research has confirmed that job satisfaction influences both the behavior of workers and the productivity of firms [27, 28].

As competitive environments globalize, a competitive advantage requires more than ownership of heavily replicated assets or resources. At present, it is just human resources, which are one of the competitive advantages and a critical factor determining the success of an enterprise. Because of increased rates of global migration, employees commonly have multicultural backgrounds [29]. In order to be effective in this context, incentive programs must be tailored to the choices and sizes of each work team and the capabilities and size of each enterprise [14]. The aim of this study is to identify the differences in the perception of the preferred level of motivation and job satisfaction in terms of enterprise size and within selected countries. It is assumed that levels of employee motivation (preferred level) and job satisfaction (current level) will vary regarding the enterprise size and the country.

\section{Materials and Methods}

Level of motivation and job satisfaction, in other words preferred level and current level, were analyzed in companies operating in the Slovak Republic and the Czech Republic in 2018. The analysis was conducted as a part of an extensive research. Research was carried out in the field of transportation as this sector represents the sector with the most significant growth of small and medium-sized enterprises [30].

A questionnaire was used to determine the level of motivation and job satisfaction, i.e. preferred and current level. The questionnaires were submitted to randomly selected employees of logistic companies in both the Slovak Republic and the Czech Republic in order to ensure variability and randomness of respondent selection necessary for relevant data acquisition. The selection of respondents was proportionately allocated across the Slovak Republic and the Czech Republic. 
Therefore, all parts of Slovak Republic and the Czech Republic were covered by the research sampling unit.

The research data were collected from 4,885 employees working in logistic companies. 690 employees from small enterprises, 720 employees from mediumsized enterprises and 1,170 employees from large companies operating in Slovakia participated in the research. In the Czech Republic, 837 employees from small enterprises, 712 employees from medium-sized enterprises and 756 employees from large companies took part in the research.

Levels of motivation and job satisfaction were analyzed by 30 motivation factors in the following structure: 1 . atmosphere in the workplace; 2 . good work team; 3 . fringe benefits; 4. physical effort at work; 5 . job security; 6 . communication in the workplace; 7 . name of the company; 8 . opportunity to apply one's own ability; 9. workload and type of work; 10. information about performance result; 11. working hours; 12. work environment; 13. job performance; 14. career advancement; 15. competences; 16. prestige; 17. supervisor's approach; 18. individual decision-making; 19. self-actualization; 20. social benefits; 21 . fair appraisal system; 22. stress; 23. mental effort; 24. mission of the company; 25. region's development; 26. personal growth; 27. relation to the environment; 28. free time; 29. recognition; 30 . basic salary.

All factors were measured on the Likert scale from 1 (the least important/satisfied) to 5 (the most important/satisfied). Except these ordinal variables, two nominal variables - the size of the company and the country of origin were used.

The aim of this study is to identify the differences in the perception of the preferred level of motivation and job satisfaction in terms of the size of enterprises and the selected countries. The following hypotheses were tested:

- Hypothesis 1: There are differences in the level of motivation and job satisfaction depending on the size of the enterprise.

- Hypothesis 2: There are differences in the level of motivation and job satisfaction depending on the country.

Within our research hypotheses, two-way ANOVA with interaction was applied. In the frame of inferential statistics, the ANOVA is an appropriate technique to consider the effect of the factor on the variable of interest. In post-hoc analysis, the Tukey's HSD test for unequal sample size was involved. Next, 0.95 confidence intervals for population means was calculated. Box plots were used for graphical interpretation of the results. For all estimates and hypothesis testing, basic descriptive statistics of our research sample was used. In hypothesis testing, 0.05 level of significance was used. All results were carried out with the statistical software STATISTICA 12. 


\section{Results and Discussion}

The overview of the descriptive statistics results as well as the interval estimates of the mean values are presented in Table 1 .

Table 1

Motivation factors - basic statistic characteristics

\begin{tabular}{|c|c|c|c|c|c|c|c|c|}
\hline \multirow{3}{*}{$\begin{array}{l}\text { Motivation } \\
\text { factor }\end{array}$} & \multicolumn{4}{|c|}{ Preferred level (motivation) } & \multicolumn{4}{|c|}{ Current level (satisfaction) } \\
\hline & \multirow[b]{2}{*}{ Mean } & \multirow{2}{*}{$\begin{array}{c}\text { St. } \\
\text { deviation }\end{array}$} & \multicolumn{2}{|c|}{ Conf. interval 95\% } & \multirow[b]{2}{*}{ Mean } & \multirow{2}{*}{$\begin{array}{c}\text { St. } \\
\text { deviation }\end{array}$} & \multicolumn{2}{|c|}{ Conf. interval 95\% } \\
\hline & & & $\begin{array}{c}\text { lower } \\
\text { limit }\end{array}$ & $\begin{array}{l}\text { upper } \\
\text { limit }\end{array}$ & & & $\begin{array}{c}\text { lower } \\
\text { limit }\end{array}$ & $\begin{array}{c}\text { upper } \\
\text { limit }\end{array}$ \\
\hline 30 & 4.54 & 1.03 & 4.51 & 4.57 & 2.99 & 1.13 & 2.96 & 3.02 \\
\hline 2 & 4.49 & 0.70 & 4.47 & 4.51 & 3.51 & 1.01 & 3.48 & 3.54 \\
\hline 1 & 4.46 & 0.75 & 4.44 & 4.48 & 3.37 & 1.02 & 3.34 & 3.40 \\
\hline 21 & 4.39 & 0.81 & 4.37 & 4.41 & 3.13 & 1.08 & 3.10 & 3.16 \\
\hline 17 & 4.37 & 0.81 & 4.35 & 4.40 & 3.33 & 1.16 & 3.30 & 3.37 \\
\hline 5 & 4.35 & 0.83 & 4.32 & 4.37 & 3.45 & 1.05 & 3.42 & 3.48 \\
\hline 3 & 4.29 & 0.81 & 4.27 & 4.31 & 3.00 & 1.06 & 2.97 & 3.03 \\
\hline 6 & 4.25 & 0.82 & 4.22 & 4.27 & 3.26 & 1.02 & 3.23 & 3.29 \\
\hline 11 & 4.14 & 0.90 & 4.12 & 4.17 & 3.38 & 1.07 & 3.35 & 3.41 \\
\hline 29 & 4.12 & 0.87 & 4.10 & 4.15 & 3.03 & 1.01 & 3.01 & 3.06 \\
\hline 12 & 4.11 & 0.84 & 4.08 & 4.13 & 3.35 & 1.03 & 3.32 & 3.37 \\
\hline 22 & 4.10 & 0.90 & 4.07 & 4.12 & 3.34 & 1.07 & 3.31 & 3.37 \\
\hline 9 & 4.06 & 0.83 & 4.04 & 4.08 & 3.40 & 0.96 & 3.37 & 3.42 \\
\hline 28 & 4.03 & 0.94 & 4.01 & 4.06 & 3.13 & 1.04 & 3.10 & 3.16 \\
\hline 20 & 4.02 & 0.92 & 4.00 & 4.05 & 3.07 & 1.05 & 3.05 & 3.10 \\
\hline 26 & 4.00 & 0.91 & 3.98 & 4.03 & 3.08 & 1.02 & 3.05 & 3.11 \\
\hline 8 & 4.00 & 0.86 & 3.97 & 4.02 & 3.22 & 1.02 & 3.19 & 3.25 \\
\hline 13 & 4.00 & 0.84 & 3.98 & 4.02 & 3.44 & 0.90 & 3.42 & 3.47 \\
\hline 23 & 3.95 & 0.92 & 3.93 & 3.98 & 3.07 & 1.00 & 3.04 & 3.09 \\
\hline 19 & 3.91 & 0.90 & 3.89 & 3.94 & 3.11 & 1.00 & 3.08 & 3.14 \\
\hline 18 & 3.90 & 0.89 & 3.88 & 3.93 & 3.22 & 0.97 & 3.19 & 3.24 \\
\hline 10 & 3.90 & 0.90 & 3.87 & 3.92 & 3.21 & 0.96 & 3.18 & 3.23 \\
\hline 14 & 3.89 & 0.87 & 3.87 & 3.92 & 3.20 & 0.92 & 3.17 & 3.22 \\
\hline 7 & 3.79 & 1.03 & 3.76 & 3.82 & 3.40 & 0.98 & 3.37 & 3.43 \\
\hline 15 & 3.78 & 0.92 & 3.76 & 3.81 & 3.02 & 0.96 & 2.99 & 3.05 \\
\hline 27 & 3.75 & 1.04 & 3.72 & 3.78 & 3.20 & 1.02 & 3.17 & 3.23 \\
\hline 24 & 3.71 & 1.00 & 3.68 & 3.74 & 3.21 & 0.95 & 3.18 & 3.24 \\
\hline 16 & 3.71 & 0.97 & 3.68 & 3.73 & 3.11 & 0.93 & 3.09 & 3.14 \\
\hline 4 & 3.60 & 0.99 & 3.58 & 3.63 & 3.21 & 1.03 & 3.18 & 3.24 \\
\hline 25 & 3.55 & 1.03 & 3.52 & 3.58 & 2.95 & 0.94 & 2.92 & 2.98 \\
\hline
\end{tabular}


Mean and standard deviation are used to define each factor for the entire sampling unit. Following the data, $95 \%$ confidence intervals were calculated for the mean values (preferred level) and satisfaction (current level) in the basic sampling unit. The data in Table 1 is ranked in descending order according to the mean value of the importance of the motivation factors at the preferred level.

In the study, the occurrence of significant differences in the perception of importance of motivation factors by employees in enterprises of varying size in two different countries and at the same time is discussed. The first four motivation factors in Table 1 were selected for a more detailed analysis. These motivation factors were marked by respondents with the highest values of importance at the preferred level. With the exception of the basic salary - factor No. 30, employees attach the greatest importance to the relationship motivation factors. These are motivation factors No. 2 - good work team, No. 1 - atmosphere in the workplace and No. 21 - fair appraisal system.

Selected motivation factors were subjected to two-dimensional scattering analysis, where two variables act as factors affecting the level of values. Country of origin with two levels - Slovakia and the Czech Republic and size of the enterprise with three levels - small, medium and large enterprise. Variables No. 30, 2, 1 and 21 were analyzed in both at preferred and current level which makes it possible to assess the situation how employees in logistics companies would like to be motivated (importance) and are really motivated (satisfaction).

Table 2

Results of two-way ANOVA: df-degree of freedom, SS-sum of square, MS- mean square, F-value of F-test $^{1}$

\begin{tabular}{|c|c|c|c|c|c|c|c|c|c|c|c|}
\hline \multirow{2}{*}{\multicolumn{2}{|c|}{ Motivation factor }} & \multicolumn{5}{|c|}{ Preferred level } & \multicolumn{5}{|c|}{ Current level } \\
\hline & & $\mathrm{df}$ & SS & MS & $\mathrm{F}$ & p-level & $\mathrm{df}$ & SS & MS & $\mathrm{F}$ & p-level \\
\hline \multirow{4}{*}{30} & Country of origin & 1 & 0.71 & 0.71 & 0.67 & 0.414 & 1 & 121.32 & 121.32 & 97.90 & 0.000 \\
\hline & Size of company & 2 & 0.46 & 0.23 & 0.22 & 0.804 & 2 & 33.99 & 16.99 & 13.71 & 0.000 \\
\hline & Interaction & 2 & 8.89 & 4.44 & 4.17 & 0.016 & 2 & 24.65 & 12.32 & 9.95 & 0.000 \\
\hline & Error & 4,879 & $5,201.27$ & 1.07 & & & 4,879 & $6,045.85$ & 1.24 & & \\
\hline \multirow{4}{*}{1} & Country of origin & 1 & 44.31 & 44.31 & 92.6 & 0.000 & 1 & 7.59 & 7.59 & 7.70 & 0.006 \\
\hline & Size of company & 2 & 12.14 & 6.07 & 12.7 & 0.000 & 2 & 128.12 & 64.06 & 65.00 & 0.000 \\
\hline & Interaction & 2 & 14.60 & 7.30 & 15.3 & 0.000 & 2 & 37.96 & 18.98 & 19.26 & 0.000 \\
\hline & Error & 4,879 & $2,333.67$ & 0.48 & & & 4,879 & $4,808.44$ & 0.99 & & \\
\hline \multirow{4}{*}{2} & Country of origin & 1 & 90.83 & 90.83 & 167.7 & 0.000 & 1 & 12.58 & 12.58 & 12.56 & 0.000 \\
\hline & Size of company & 2 & 23.63 & 11.82 & 21.8 & 0.000 & 2 & 110.68 & 55.34 & 55.26 & 0.000 \\
\hline & Interaction & 2 & 9.18 & 4.59 & 8.5 & 0.000 & 2 & 38.37 & 19.19 & 19.16 & 0.000 \\
\hline & Error & 4,879 & $2,641.68$ & 0.54 & & & 4,879 & $4,885.48$ & 1.00 & & \\
\hline
\end{tabular}

1 note: statistically significant differences are highlighted in bold 


\begin{tabular}{|c|c|c|c|c|c|c|c|c|c|c|c|}
\hline \multirow{4}{*}{21} & Country of origin & 1 & $\mathbf{4 . 5 6}$ & $\mathbf{4 . 5 6}$ & $\mathbf{7 . 0}$ & $\mathbf{0 . 0 0 8}$ & 1 & $\mathbf{4 1 . 9 1}$ & $\mathbf{4 1 . 9 1}$ & $\mathbf{3 7 . 0 2}$ & $\mathbf{0 . 0 0 0}$ \\
\cline { 2 - 11 } & Size of company & 2 & $\mathbf{4 8 . 8 4}$ & $\mathbf{2 4 . 4 2}$ & $\mathbf{3 7 . 7}$ & $\mathbf{0 . 0 0 0}$ & 2 & $\mathbf{5 5 . 0 4}$ & $\mathbf{2 7 . 5 2}$ & $\mathbf{2 4 . 3 1}$ & $\mathbf{0 . 0 0 0}$ \\
\cline { 2 - 11 } & Interaction & 2 & $\mathbf{1 1 . 8 7}$ & $\mathbf{5 . 9 3}$ & $\mathbf{9 . 2}$ & $\mathbf{0 . 0 0 0}$ & 2 & $\mathbf{8 0 . 3 7}$ & $\mathbf{4 0 . 1 8}$ & $\mathbf{3 5 . 5 0}$ & $\mathbf{0 . 0 0 0}$ \\
\hline & Error & 4,879 & $3,163.47$ & 0.65 & & & 4,879 & $5,522.79$ & 1.13 & & \\
\hline
\end{tabular}

Table 2 summarizes the results of the F-test, which is the essence of the scattering analysis. On the basis of p-levels, it can be said that significant differences in the mean values of importance and satisfaction with the motivation factors observed are the results of interaction between the two observed factors. With the exception of the basic salary at the preferred level, there are also significant differences in the mean values of importance from the point of view of the individual factors alone. Both factors significantly affect the values of importance of motivation basic salary (No. 30), however, only in interaction.

Following the results of the scattering analysis, the fact that the motivation of employees working in logistics companies is different in Slovakia and in the Czech Republic and motivation varies also depending on the fact whether employees work in small, medium or large enterprises can be concluded. As part of the post-hoc analysis, the observed dependencies of the mean values of importance and satisfaction of two factors were examined in more detail. The results are presented separately by individual factors. A focus will be put on a deeper analysis of the issue as required because of a priority to know what way employees need to be motivated. Paired test results are presented in box plots representing confidence intervals of $95 \%$ for the average values of the given motivation factors in both at the preferred and current level.

\subsection{Motivation Factor No. 30 - Basic Salary}

The Tukey's HSD post-hoc test results are shown in Table 3. In a pairwise comparison, it can be observed that, at the preferred level, all employees perceive the basic salary as a strong motivating factor, whether in Slovakia or in the Czech Republic, in companies of varying sizes.

Table 3

Basic salary: pairwise comparison, p-levels of Tukey's HSD test ${ }^{2}$

\begin{tabular}{|c|c|c|c|c|c|c|}
\hline & \multicolumn{7}{|c|}{ Preferred level - above the diagonal } \\
\hline & SVK-small & SVK-medium & SVK-large & CZ-small & CZ-medium & CZ-large \\
\hline SVK-small & - & 0.160 & 0.685 & 0.581 & 1.000 & 0.964 \\
\hline SVK-medium & 1.000 & - & 0.935 & 0.971 & 0.179 & 0.596 \\
\hline SVK-large & $\mathbf{0 . 0 0 0}$ & $\mathbf{0 . 0 0 0}$ & - & 1.000 & 0.726 & 0.984 \\
\hline CZ-small & $\mathbf{0 . 0 0 0}$ & $\mathbf{0 . 0 0 0}$ & $\mathbf{0 . 0 0 2}$ & - & 0.623 & 0.959 \\
\hline
\end{tabular}

2 note: statistically significant differences are highlighted in bold 


\begin{tabular}{|c|c|c|c|c|c|c|}
\hline CZ-medium & $\mathbf{0 . 0 0 0}$ & $\mathbf{0 . 0 0 0}$ & 0.996 & $\mathbf{0 . 0 3 0}$ & - & 0.977 \\
\hline CZ-large & $\mathbf{0 . 0 0 0}$ & $\mathbf{0 . 0 0 0}$ & 0.083 & 0.932 & 0.292 & - \\
\hline \multicolumn{6}{|c|}{ Current level - below the diagonal } \\
\hline
\end{tabular}

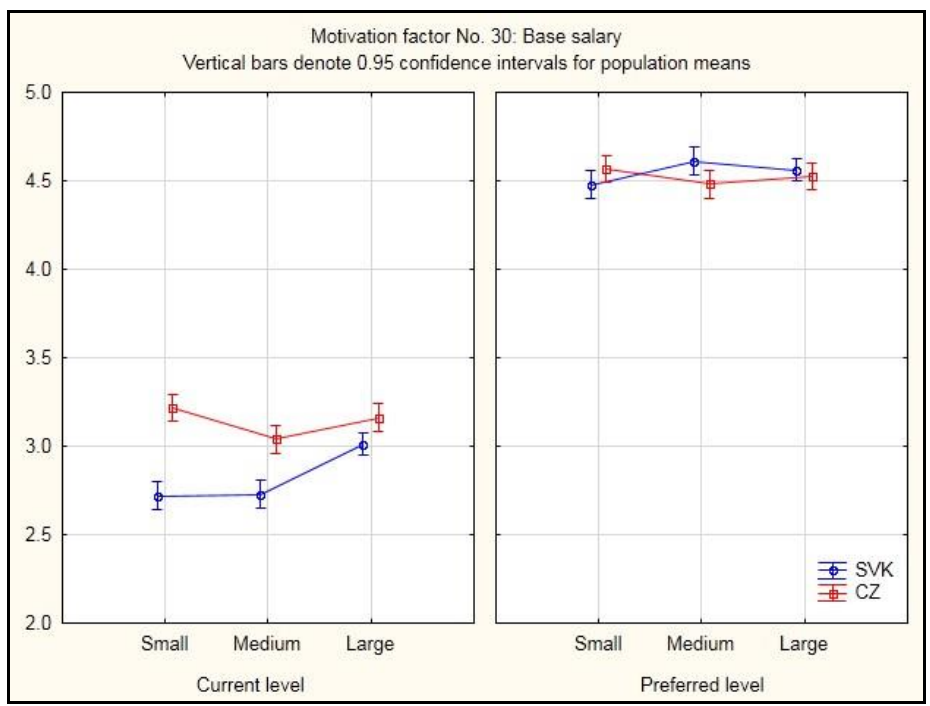

Figure 1

Box plot - Basic salary

In perceiving the real level of motivation, employees in small and medium-sized enterprises in the Czech Republic are more satisfied with salaries than employees working in companies of a given size in Slovakia. Opinions of employees working in large Slovak and Czech enterprises are not different in satisfaction with the basic salary at the level of significance $\alpha=0.05$.

Figure 1 presents $95 \%$ confidence intervals for the mean values of the importance of the motivation factor - basic salary in both at the preferred and current level. It is clear that employees working in logistics companies, irrespective of their country and enterprise size, evaluate their actual motivation by a basic salary in a neutral way, i. e. the mean value of importance is around 3 (Figure 1 on the left). Figure 1 on the right shows the priority of basic salary for the employees (mean values around 4.5 and above).

\subsection{Motivation Factor No. 2 - Good Work Team}

The pairwise comparison results are presented in Table 4 showing the significant differences in mean values of importance at the preferred level. The greatest importance is attributed to the good work team by employees in large Czech enterprises. There is the statistically significant difference in their views from the 
rest of the groups. An equal level of importance is attributed to a good work team by employees working in Czech small and medium-sized enterprises. The same level of values of importance is attributed by employees working in Slovak medium-sized enterprises. Opinions of employees working in small and large Slovak enterprises differ from other groups surveyed, but not from each other. In general, respondents attribute the lowest value of importance to a good work team.

Job satisfaction is presented in Table 4 and Figure 2 on the left.

Table 4

Good work team: pairwise comparison, p-levels of Tukey's HSD test ${ }^{3}$

\begin{tabular}{|c|c|c|c|c|c|c|}
\hline & \multicolumn{7}{|c|}{ Preferred level - above the diagonal } \\
\hline & SVK-small & SVK-medium & SVK-large & CZ-small & CZ-medium & CZ-large \\
\hline SVK-small & - & $\mathbf{0 . 0 0 0}$ & 0.085 & $\mathbf{0 . 0 0 0}$ & $\mathbf{0 . 0 0 0}$ & $\mathbf{0 . 0 0 0}$ \\
\hline SVK-medium & 0.063 & - & $\mathbf{0 . 0 0 9}$ & 0.873 & 0.941 & $\mathbf{0 . 0 0 0}$ \\
\hline SVK-large & $\mathbf{0 . 0 0 0}$ & $\mathbf{0 . 0 0 0}$ & - & $\mathbf{0 . 0 0 0}$ & $\mathbf{0 . 0 0 0}$ & $\mathbf{0 . 0 0 0}$ \\
\hline CZ-small & $\mathbf{0 . 0 0 8}$ & $\mathbf{0 . 0 0 0}$ & $\mathbf{0 . 0 0 0}$ & - & 1.000 & $\mathbf{0 . 0 1 1}$ \\
\hline CZ-medium & 0.742 & $\mathbf{0 . 0 0 0}$ & $\mathbf{0 . 0 0 0}$ & 0.301 & - & $\mathbf{0 . 0 0 8}$ \\
\hline CZ-large & $\mathbf{0 . 0 0 0}$ & $\mathbf{0 . 0 0 0}$ & $\mathbf{0 . 0 1 7}$ & 0.560 & $\mathbf{0 . 0 0 3}$ & - \\
\hline & \multicolumn{7}{|c|}{ Current level-below the diagonal } \\
\hline
\end{tabular}

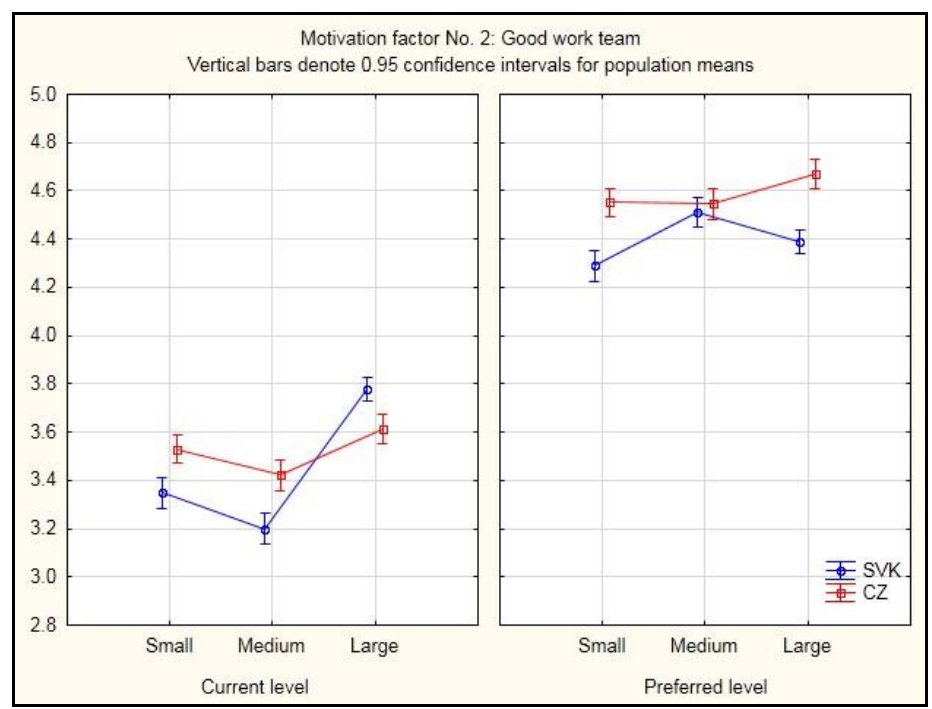

Figure 2

Box plot - Good work team

3 note: statistically significant differences are highlighted in bold 
Employees of large Slovak companies are the most satisfied with their work team. The results are significantly different from the remaining groups. Employees working in medium-sized and small Slovak enterprises rated their work teams with lower marks of satisfaction than the Czech respondents.

Figure 2 presents $95 \%$ confidence intervals for the mean values of the importance of the motivation factor - good work team. The difference in the mean values between preferred and current level is observed, i. e. between employee satisfaction with a given factor in their real working conditions and their need to be motivated by a good work team.

\subsection{Motivation Factor No. 1 - Atmosphere in the Workplace}

The results of post-hoc testing are presented in Table 5. Employees of all Czech enterprises, irrespective of size, rate the atmosphere in the workplace equally important. On a scale of importance, they assess this factor with higher average values than employees working in Slovak logistics companies. In Slovak enterprises, the views of employees working in small enterprises differ from those of employees working in medium-sized and large enterprises. Respondents attribute to the atmosphere in the workplace the lowest average value of all groups. Employees of middle-sized and large enterprises, regardless of their country, are equally satisfied with the atmosphere in the workplace. The opinions of employees working in small Slovak and small Czech enterprises differ significantly.

Table 5

Atmosphere in the workplace: pair-wise comparison, p-levels of Tukey's HSD test ${ }^{4}$

\begin{tabular}{|c|c|c|c|c|c|c|}
\hline & \multicolumn{7}{|c|}{ Preferred level - above the diagonal } \\
\hline & SVK-small & SVK-medium & SVK-large & CZ-small & CZ-medium & CZ-large \\
\hline SVK-small & - & $\mathbf{0 . 0 0 0}$ & $\mathbf{0 . 0 0 0}$ & $\mathbf{0 . 0 0 0}$ & $\mathbf{0 . 0 0 0}$ & $\mathbf{0 . 0 0 0}$ \\
\hline SVK-medium & 0.972 & - & 0.734 & $\mathbf{0 . 0 1 2}$ & $\mathbf{0 . 0 0 0}$ & $\mathbf{0 . 0 0 0}$ \\
\hline SVK-large & $\mathbf{0 . 0 0 0}$ & $\mathbf{0 . 0 0 0}$ & - & $\mathbf{0 . 0 0 0}$ & $\mathbf{0 . 0 0 0}$ & $\mathbf{0 . 0 0 0}$ \\
\hline CZ-small & $\mathbf{0 . 0 0 0}$ & $\mathbf{0 . 0 0 0}$ & 0.481 & - & 0.856 & 0.262 \\
\hline CZ-medium & 0.980 & 0.659 & $\mathbf{0 . 0 0 0}$ & $\mathbf{0 . 0 0 0}$ & - & 0.940 \\
\hline CZ-large & $\mathbf{0 . 0 0 0}$ & $\mathbf{0 . 0 0 0}$ & 0.374 & 1.000 & $\mathbf{0 . 0 0 0}$ & - \\
\hline & \multicolumn{7}{|c|}{ Current level - below the diagonal } \\
\hline
\end{tabular}

Figure 3 presents $95 \%$ confidence intervals for the average values of the importance of the motivation factor - atmosphere in the workplace. A clear discrepancy between employee assessment of the atmosphere in their workplace (Figure 3 on the left) and how much importance they attribute to this factor in their work motivation (Figure 3 on the right) is observed.

4 note: statistically significant differences are highlighted in bold 


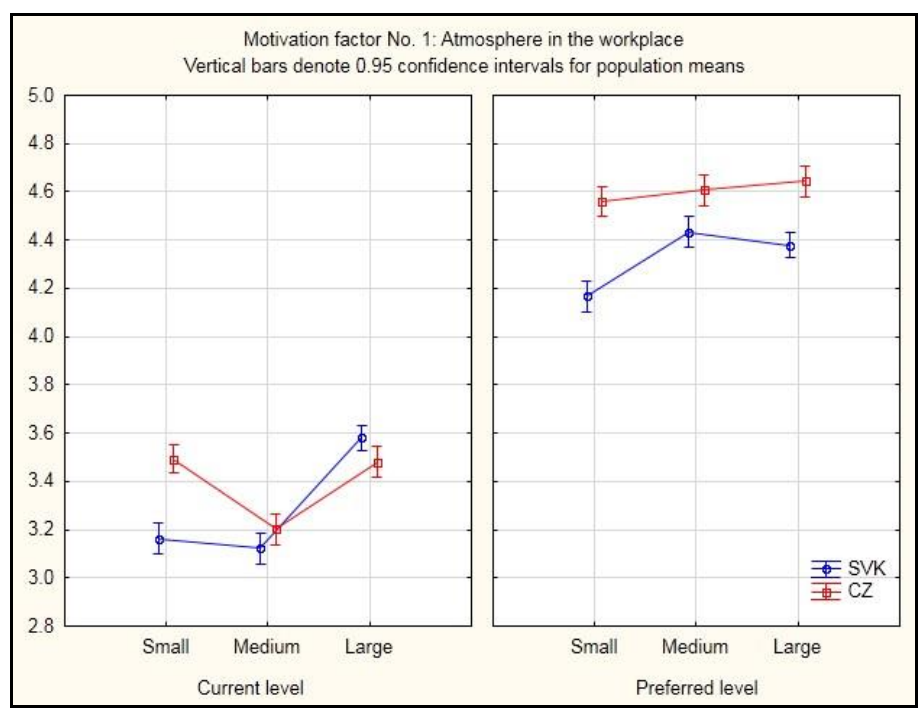

Figure 3

Box plot - Atmosphere in the workplace

\subsection{Motivation Factor No. 21 - Fair Appraisal System}

Table 6 presents Tukey's HSD test results.

\section{Table 6}

Fair appraisal system: pairwise comparison, p-levels of Tukey's HSD test ${ }^{5}$

\begin{tabular}{|c|c|c|c|c|c|c|}
\hline & \multicolumn{7}{|c|}{ Preferred level - above the diagonal } \\
\hline & SVK-small & SVK-medium & SVK-large & CZ-small & CZ-medium & CZ-large \\
\hline SVK-small & - & $\mathbf{0 . 0 0 0}$ & $\mathbf{0 . 0 0 0}$ & $\mathbf{0 . 0 0 0}$ & $\mathbf{0 . 0 0 0}$ & $\mathbf{0 . 0 0 0}$ \\
\hline SVK-medium & $\mathbf{0 . 0 0 0}$ & - & 0.997 & $\mathbf{0 . 0 3 2}$ & 0.692 & 0.952 \\
\hline SVK-large & $\mathbf{0 . 0 0 0}$ & $\mathbf{0 . 0 0 1}$ & - & 0.068 & 0.919 & 0.742 \\
\hline CZ-small & $\mathbf{0 . 0 0 0}$ & $\mathbf{0 . 0 0 0}$ & 0.537 & - & 0.646 & $\mathbf{0 . 0 0 1}$ \\
\hline CZ-medium & $\mathbf{0 . 0 0 0}$ & 1.000 & $\mathbf{0 . 0 0 0}$ & $\mathbf{0 . 0 0 0}$ & - & 0.182 \\
\hline CZ-large & $\mathbf{0 . 0 0 0}$ & $\mathbf{0 . 0 0 0}$ & 0.999 & 0.821 & $\mathbf{0 . 0 0 0}$ & - \\
\hline \multicolumn{7}{|c|}{ Current level - below the diagonal } \\
\hline
\end{tabular}

When examining the preferred level, the opinions of employees working in small Slovak enterprises are significantly different from other respondents. Compared to other groups of enterprises, respondents perceive fair appraisal of employees as

5 note: statistically significant differences are highlighted in bold 
the lowest mean value of importance. Employees working in medium and large enterprises, regardless of country, perceive the motivation factor in the same way.

Respondents in small Slovak enterprises attribute the lowest mean value to work satisfaction. These results are significantly different from the rest of the groups surveyed.

Figure 4 shows $95 \%$ confidence intervals for the mean values of the importance of the motivation factor - fair appraisal system. Fair appraisal of employees is considered a factor of great importance by employees in logistics companies in their work motivation (Figure 4 on the right). However, the real situation in fair appraisal system is perceived in a different way. Mean values of job satisfaction are at a neutral level in the rating scale (Figure 4 on the left) with a more pronounced difference between small enterprises in Slovakia and the Czech Republic.

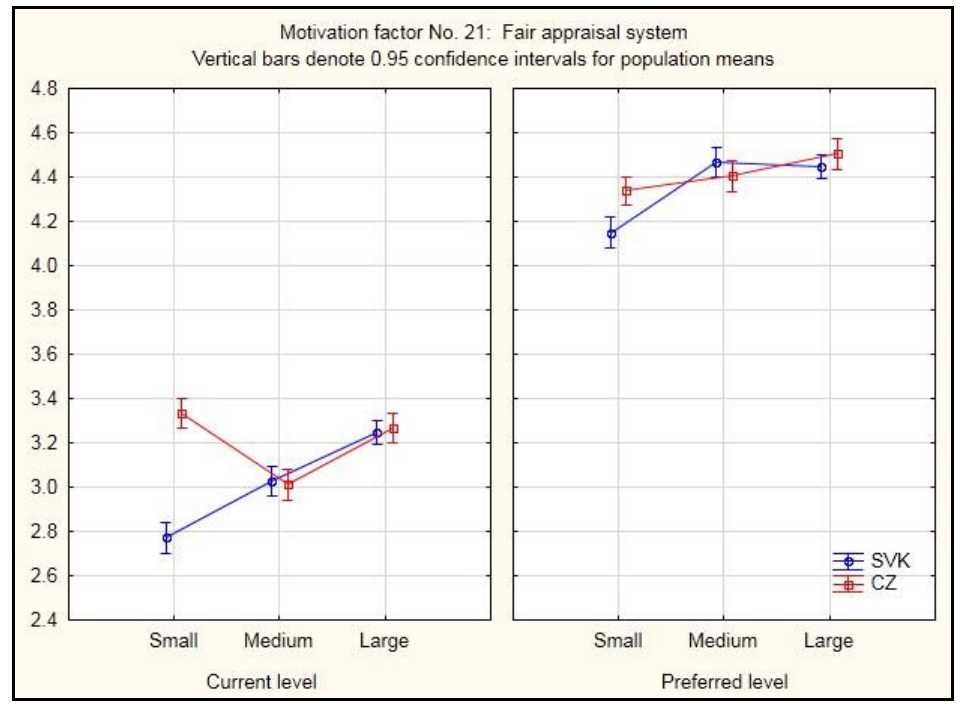

Figure 4

Box plot - Fair appraisal system

Small and medium-sized enterprises constitute a major part of the economy of each country with the greatest potential for growth and the impact on economic stabilization and balanced development of the regions [31]. They are one of the biggest drivers of regional development as they are important in creating jobs and creating an entrepreneurial spirit $[32,33]$. Considering the growing economy that is creating new opportunities, no business entity (small, medium or large) is able to satisfy the customer by delivering the right product, in the right quality, in the right amount, in the right place, at the right time, at the right price, and reasonable costs in a tough competitive environment $[34,35]$. 
At present, logistics is becoming the center of attention more and more frequently. This is an area that is affected by the globalization of world trade, the explosion of information and communication technologies, the growing importance of system approach, the concept of total costs and the orientation of the enterprise to top quality as well as high-level of customer service [36, 37]. The progressive growth of the economy in this sector brings a rapid progress in the field of innovations, in which sustainable innovation management has its irreplaceable place. Thanks to the fact that logistics in the Slovak Republic and the Czech Republic has become part of European and global trade, logistics providers are involved in transnational production and distribution chains and in the application of modern procedures. In this context, the lack of qualified workers is the biggest challenge for Slovak and Czech small, medium-sized and large enterprises. Nearly three quarters $(71 \%)$ of the respondents agree to this in the study published by Casey [38]. For logistics companies, this situation presents the challenge and the necessity not only to acquire but also to maintain good human resources. Therefore, business strategies are geared towards achieving sustainable processes. Employer branding is becoming an important part of a business strategy [39, 40]. This approach includes progressive HR activities so that the employers proactively differentiates themselves from their competitors and maintains and attracts as many new highquality employees as possible [41, 42]. Employer branding uses a variety of original employee-oriented tools [43, 44]. In order to succeed, to ensure sustainability, to build a reputation for business and a strong brand, companies meet their employees' needs by providing good working conditions [45, 46]. An interest in the level of employee motivation and employee satisfaction is becoming of vital importance [20,22]. In this context, the role of managers is to respect the principles of sustainability while taking into account the size of the enterprise, because according to the results of previous research, job satisfaction levels are lower in large enterprises and management-employee relationships are less satisfactory in large enterprises than in small enterprises [19, 21]. The findings by Artz [28] indicate that net performance pay increases job satisfaction in larger enterprises. Improving management-employee relations in large enterprises will increase employee satisfaction in many respects as well as increase productivity and reduce turnover [19].

Multicultural teams of workers are becoming current trends in logistics companies [47]. Thanks to the global nature of logistics, they have become a reality in logistics companies. Organizations with competitors increasingly global, require managers who excel in managing culturally diverse, very complex and rapidly changing conditions [29, 48]. Intercultural (global) competencies and the emphasis on effective management from an intercultural point of view, which means an increased tolerance to cultural differences, while taking into account different values, priorities and therefore different motivational elements, are indispensable for managers working in intercultural teams. Research results by Blašková and Hitka [14], Daud [22], Nastacă [49], Nikulin and Szymczak [50], Seilerová [51], Extremera et al. [52], Kim and Choi [53], Sanchez-Sellero et al. 
[54], Žul'ová et al. [55], Malá et al. [56], and Kamdron [57] confirm that adequate managing of intercultural aspects results in increased satisfaction, motivation and improved work performance of employees.

\section{Conclusions}

The aim of this study was to identify differences in the perception of motivation and job satisfaction of employees in selected countries. Based on the research results, the fact that motivation of employees in the logistics industry is different in Slovakia and in the Czech Republic can be concluded. At the same time, motivation varies in terms of the size of enterprise. As part of the post-hoc analysis, the observed dependencies of the mean values of motivation and satisfaction with the effects of the selected motivation factors were examined in more detail. These findings are important for the members of management because of the globalization of economies and multiculturalism of teams, in (but not only) logistics companies. Finding a variety of preferences for motivational needs and job satisfaction does not make it possible to develop unified motivation programs. Finally, the fact that the company management has to take into account the needs of its employees with regard to the size of an enterprise as well as the country of origin can be stated.

\section{Acknowledgement}

This research was supported by projects KEGA 005TU Z-4/2020 "Economics, Management and Enterprising in Wood Industry Companies - university textbook with visualization support in virtual space".

\section{References}

[1] M. Wosiek: Rural-Urban Divide in Human Capital in Poland after 1988. Oeconomia Copernicana, Vol. 11, 2020, No. 1, pp. 183-201

[2] P. Sánchez-Sellero, M. C. Sánchez-Sellero, F. J. Sánchez-Sellero, M. M. Cruz-González: Innovation and Manufacturing Productivity. Journal of Technology Management and Innovation, Vol. 9, 2014, No. 3, pp. 135-145

[3] J. Horecký, M. Blažek: Dependent Work and Internship. Central European Journal of Labour Law and Personnel Management, Vol. 2, 2019, No. 2, pp. 7-20

[4] E. Nedeliaková, M. Panak: Methodology for Quality Assessment within Transportation Chain. Proceedings of CITPM, Czestochawa (Poland), 2016, pp. 309-214

[5] The European Commission. User Guide to the SME Defiinition, Publications Office of the European Union, Luxemburg, 2015

[6] Definice velkého podniku. (In English - Definition of a Large Enterprise.) Availbale online: http://www.50001.cz/definice-velkeho-podniku/ (accessed on 27 November 2018) 
[7] Malé podniky zamestnávajú na Slovensku viac než polovicu l'udí, je to piaty najvyšší podiel v EÚ (In English - Small Businesses Employ More Than Half of the People in Slovakia, the Fifth Highest Share in the EU.) Available online: https://touchit.sk/male-podniky-zamestnavaju-naslovensku-viac-nez-polovicu-ludi-je-to-piaty-najvyssi-podiel-v-eu/180486 (accessed on 27 November 2018)

[8] SBA. Malé a stredné podnikanie v číslach v roku 2017 (In English - Small and Medium Business in Numbers in 2017) Available online: https://www.npc.sk/file?uuid=b40742be-ac93-4fd0-ae60-b52467626139 (accessed on 27 November 2018)

[9] Zpráva o vývoji malého a středního podnikání a jeho podpoře v roce 2017 (In English - Report on the Development of Small and Medium-Sized Enterprises and their Support in 2017) Availbale online: https://www.mpo.cz/assets/cz/podnikani/male-a-stredni-podnikani/studie-astrategicke-dokumenty/2018/10/Zprava_MSP_2017.pdf (accessed on 30 November 2018)

[10] J. Kubal'a, M. Vetráková: Reasons of the Employees' Stabilization in Hotels in Slovakia. Acta Oeconomica Universitatis Selye, Vol. 6, 2018, No. $2,90-100$

[11] M. Nosková, T. Peráček: Termination of Employment in the Slovak Republic as a Key Issue of HR Management. Central European Journal of Labour Law and Personnel Management, Vol. 2, 2019, No. 2, pp. 44-59, doi: 10.33382/cejllpm.2019.03.04

[12] M. Vokoun, Z. Caha, J. Straková, F. Stellner, J. Váchal: The Strategic Importance of Human Resources Management and the Roles of Human Capital Investment and Education. SCIPAP, Vol. 25, 2018, No. 42, pp. 258-268

[13] D. Gottwald, L. Svadlenka, P. Lejskova, H. Pavlisova: Human Capital as a Tool for Predicting Development of Transport and Communications Sector: The Czech Republic Perspective. Communications - Scientific Letters of the University of Zilina, Vol. 19, 2017, No. 4, pp. 50-56

[14] M. Blašková, M. Hitka: Model Riadenia Pracovnej Motivácie v Priemyselných Podnikoch (In English - Work Motivation Management Model in Industrial Enterprises) Technical University in Zvolen, Zvolen, Slovakia, 2011

[15] A. Aydin, S. Tiryaki: Impact of Performance Appraisal on Employee Motivation and Productivity in Turkish Forest Products Industry. Drvna Industrija, Vol. 69, 2018, No. 2, pp. 101-111

[16] A. Tansel, S. Gazioglu: Management-Employee Relations, Firm Size and Job Satisfaction. International Journal of Manpower, Vol. 35, 2012, pp. $1260-1275$ 
[17] A. Al Mamun, M. D. Ibrahim, M. N. H. B. Yusoff, S. A. Fazal: Entrepreneurial Leadership, Performance, and Sustainability of Microenterprises in Malaysia. Sustainability, Vol. 10, 2018

[18] L. Mura, B. Gontkovicova, E. Dulova Spisakova, Z. Hajduova: Position of Employee Benefits in Remuneration Structure. Transformations in Business \& Economics, Vol. 18, 2019, No. 2, pp. 156-173

[19] S. Cantele, A. Zardini: Is Sustainability a Competitive Advantage for Small Businesses? Journal of Cleaner Production, Vol. 182, 2018, pp. 166-176

[20] R. Kanfer, G. Chen, R. D. Pritchard: Work Motivation: Past, Present and Future. Routledge, New York, NY, USA, 2012

[21] B. Roxas, N. Ashill, D. Chadee: Effects of Entrepreneurial and Environmental Sustainability Orientations on Firm Performance. Journal of Small Business Management, Vol. 55, 2017, No. S1, pp. 163-178

[22] N. Daud: Determinants of Job Satisfaction. In Proceedings of BSS, Kuala Lumpur, Malaysia, 2015

[23] D. Jelačić, T. Grladinović, A. Pirc, L. Oblak: Motivation Factors Analysis in Industrial Plants. Strojarstvo, Vol. 52, 2010, No. 3, pp. 349-361

[24] L. Mura, D. Vlacseková: Motivation of Public Employees: Case Study of Slovak Teaching and Professional Staff. Administratie si Management Public, Vol. 31, 2018, pp. 67-80

[25] J. Jeong, M. Choi: The Expected Job Satisfaction Affecting Entrepreneurial Intention as Career Choice in the Cultural and Artistic Industry. Sustainability, Vol. 9, 2017

[26] J. Rosak-Szyrocka: Empoyees Motivation at Hospital as a Factor of the Organizational Success. Human resources Management \& Ergonomics, Vol. 8, 2014, No. 2, pp. 102-111

[27] Z. Stacho, H. Urbancová, K. Stachová: Organisational Arrangement of Human Resources Management in Organisations Operating in Slovakia and Czech Republic. Acta Universitatis Agriculturaeet Silviculturae Mendelianae Brunensis, Vol. 61, 2013, No. 7, pp. 2787-2799

[28] B. Artz: The Role of Firm Size and Performance Pay in Determining Employee Job Satisfaction. Labour, Vol. 22, 2008, No. 2, pp. 315-343

[29] M. Szymanski, S. R. Fitzsimmons, W. M. Danis: Multicultural Managers and Competitive Advantage. International Business Review, Vol. 28, 2018, No. 2, pp. 305-315

[30] E. Dul'ová Spišáková, L. Mura, B. Gontkovičová, Z. Hajduová: R\&D in the Context of Europe 2020 in Selected Countries. Economic Computation and Economic Cybernetics Studies and Research, Vol. 51, 2017, No. 4, pp. 243 261 
[31] A. Kucharčíková, M. Mičiak: Human Capital Management in Transport Enterprises with the Acceptance of Sustainable Development in the Slovak Republic. Sustainability, Vol. 10, 2018

[32] M. Němec, L. Krišták, P. Hockicko, Z. Danihelová, K. Velmovská: Application of Innovative P\&E Method at Technical Universities in Slovakia. Eurasia Journal of Mathematics Science and Technology Education, Vol. 13, 2017, No. 6, pp. 2329-2349

[33] B. Antonová, J. Chocholáč, I. Drahotský: The Analysis of the Dependence of the Road Transport Infrastructure and Transport Performances in the Relation with GDP of the Czech Republic. SCIPAP, Vol. 36, 2016, No. 1, pp. 5-16

[34] B. Sarkan, O. Stopka, C. Li: The Issues of Measuring the Exterior and Interior Noise of Road Vehicles. Communications, Vol. 19, 2017, No. 2, pp. 50-55

[35] L. Bajzíkova, D. Novackova, D. Saxunova: Globalization in the Case of Automobile Industry in Slovakia. In Proceedings of IBIMA, Madrid, Spain, 2017

[36] E. Tokarčíková, A. Kucharčíková, M. Ďurišová: Corporate Social Responsibility Managers and their Decision Making. Turkish Online Journal of Educational Technology, 2017, pp. 654-664

[37] M. Gejdos, M. Lieskovsky, M. Slancik, M. Němec, Z. Danihelová: Storage and Fuel Quality of Coniferous Wood Chips. BioResources, Vol. 10, 2015, No. 3, pp. 5544-5553

[38] S. Casey: Global Business Monitor 2017, Bibby Financial Services

[39] A. M. Sivertzen, E. R. Nilsen, A. H. Olafsen: Employer branding. Journal of Product \& Brand Management, Vol. 22, 2013, pp. 473-483

[40] D. Kucherov, E. Zavyalova: HRD Practices and Talent Management in the Companies with the Employer Brand. European Journal of Training and Development, Vol. 36, 2012, No. 1, pp. 86-104

[41] A. Raziq, R. Maulabakhsh: Impact of Working Environment on Job Satisfaction. Procedia Economics and Finance, Vol. 23, 2015, pp. 717-725

[42] E. Loučanová, M. Olšiaková, M. Dzian: Suitability of Innovative Marketing Communication Forms in the Furniture Industry. Acta Facultatis Xylologiae Zvolen, Vol. 60, 2018, No. 1, pp. 159-171

[43] M. Sedliačiková, Z. Stroková, J. Klementová, A. Šatanová, M. Moresová: Impacts of Behavioral Aspects on Financial Decision-Making of Owners of Woodworking and Furniture Manufacturing and Trading Enterprises. Acta Facultatis Xylologiae Zvolen, Vol. 62, 2020, No. 1, pp. 165-176 
[44] M. Sedliačiková, Z. Stroková, J. Drábek, D. Malá.: Controlling Implementation: What are the Benefits and Barries for Employees of Wood Processing Enterprises? Acta Facultatis Xylologiae Zvolen, Vol. 61, 2019, No. 2, pp. 163-173

[45] H. Palus, J. Parobek, M. Dzian, S. Šimo-Svrček, M. Krahulcová: How Companies in the Wood Supply Chain Perceive the Forest Certification. Acta Facultatis Xylologiae Zvolen, Vol. 61, 2019, No. 1, pp. 155-165

[46] J. Dirisu, R. Worlu, A. Osibanjo, O. Salau, T. Borishade, S. Meninwa, T. Atolagbe: An Integrated Dataset on Organisational Culture, Job Satisfaction and Performance in the Hospitality Industry. Data in Brief, Vol. 19, 2018, pp. 317-321

[47] T. Johánek: Nedostatek lidí v obchodech a dopravě zboží tlačí nejen na vyšší mzdy (In English - The Lack of People in Shops and the Transport of Goods is not Only Pushing for Higher Wages) Available online: http://www.dnoviny.cz/spedice-logistika/nedostatek-lidi-v-obchodech-adoprave-zbozi-tlaci-nejen-na-vyssi-mzdy (accessed on 11 December 2018)

[48] N. Mikušová, M. Timák, G. Fedorko, V. Molnár: Design of New Effective Train Traffic Diagram for a Railway Line. In Proceedings of MATEC, 2018

[49] C. C. Nastacă: Leadership and Resilience in Romanian Public Administration from County Level. Administratie si Management Public, Vol. 34, 2020, pp. 78-96

[50] D. Nikulin, S. Szymczak: Effect of the Integration into Global Value Chains on the Employment Contract in Central and Eastern European countries. Equilibrium. Quarterly Journal of Economics and Economic Policy, Vol. 15, 2020, No. 2, pp. 275-294

[51] M. Seilerová: The Consequences of Psychosocial Risks in the Workplace in Legal Context. Central European Journal of Labour Law and Personnel Management, Vol. 2, 2019, No. 1, pp. 47-60

[52] N. Extremera, S. Mérida-López, N. Sánchez-Álvarez, C. Quintana-Orts: How does Emotional Intelligence Make One Feel Better at Work? International Journal of Environmental Research and Public Health, Vol. 15, 2018, No. 9

[53] S. J. Kim, S. O. Choi: The Effects of Job Mismatch on Pay, Job Satisfaction, and Performance. Journal of Open Innovation, Vol. 4, 2018

[54] M. C. Sanchez-Sellero, P. Sanchez-Sellero, M. M. Cruz-Gonzalez, F. J. Sanchez-Sellero: Determinants of Job Satisfaction in the Spanish Wood and Paper Industries. Drvna Industrija, Vol. 69, 2018, No. 1, pp. 71-80 
[55] J. Žul'ová, M. Švec, A. Madleňák: Personality Aspects of the Employee and their Exploration from the GDPR Perspective. Central European Journal of Labour Law and Personnel Management, Vol. 1, 2018, No. 1, pp. 68-77

[56] D. Malá, M. Sedliačiková, M. Dušak, A. Kaščáková, Z. Musová, J. Klementová: Green Logistics in the Context of Sustainable Development in Small and Medium Enterprises. Drvna Industrija, Vol. 68, 2017, pp. 69-79

[57] T. Kamdron: Work Motivation and Job Satisfaction of Estonian Higher Officials. International Journal of Public Administration, Vol. 28, 2005, No. 13-14 